\title{
Epilepsi ved gliom
}

\author{
Sammendrag \\ Bakgrunn. Epileptiske anfall er et \\ hyppig symptom hos pasienter med \\ primær hjernesvulst, gliom. I artikke- \\ len diskuteres epileptogenese, medika- \\ mentvalg og oppfølging hos disse \\ pasientene.
}

Kunnskapsgrunnlag. Artikkelen bygger på et søk i PubMed med artikkelutvalg basert på forfatternes skjønnsmessige vurdering og kliniske erfaring med pasientgruppen.

Resultater. Epileptiske anfall er et vanlig symptom ved gliom, spesielt ved de lavgradige formene. Bakgrunnen for epilepsi ved gliom er multifaktoriell, og svulstens molekylærbiologiske egenskaper er sannsynligvis sentrale i epileptogenesen. Effektiv behandling av epileptiske anfall er av stor betydning for gliompasientens livskvalitet. Anfallshyppighet og effekt av antiepileptisk behandling varierer, og noen pasienter trenger behandling med flere antiepileptika. Kirurgisk og onkologisk behandling av svulsten vil ofte også redusere anfallsfrekvensen.

Fortolkning. Generelt bør antiepileptika uten enzyminduserende egenskaper og med lav proteinbinding foretrekkes til pasienter med gliom. Dette vil redusere risikoen for interaksjoner med kjemoterapi eller steroidbehandling. Pasienter med hjernesvulster er spesielt utsatt for påvirkning av våkenhet, stemningsleie og kognisjon, og dette bør man ta hensyn til ved valg av medikament og i oppfølgingen. Hematologisk status bør overvåkes særlig nøye ved samtidig bruk av kjemoterapi og antiepileptika som kan påvirke beinmargsfunksjonen.

\section{Kathrine Lian}

Nevrologisk avdeling

Haukeland universitetssykehus

\section{Bernt Engelsen}

Anette Storstein

anette.storstein@helse-bergen.no

Nevrologisk avdeling

Haukeland universitetssykehus

og

Institutt for klinisk medisin

Universitetet i Bergen

Symptomatisk epilepsi er vanlig hos pasienter med gliom og kan være vanskelig å behandle. Hyppige epileptiske anfall reduserer pasientens livskvalitet $\mathrm{i}$ betydelig grad og krever god oppfølging. Pasientgruppen behandles av flere spesialistgrupper, spesielt nevrokirurger, onkologer og nevrologer, men også av andre sykehusleger og fastleger.

I det følgende gir vi en oversikt over håndtering av epilepsi hos voksne pasienter med gliom.

\section{Kunnskapsgrunnlag}

Artikkelen bygger på forfatternes kliniske erfaring og et søk i engelskspråklige artikler i PubMed med søkeordene «brain tumor», «tumor cerebri», «glioma», «glioblastoma» og «chemotherapy in glioma» kombinert med søkeordene «epilepsy», «seizure» og «antiepileptic drug». Både originalartikler og oversiktsartikler er vurdert. Hovedvekten er lagt på sentrale artikler fra de siste ti år (oppdatert per desember 2011), men der nyere data ikke foreligger, har vi også inkludert eldre publikasjoner.

\section{Epidemiologi}

Epilepsi er blant de vanligste nevrologiske sykdommene og har en insidens på 40-70/ 100 000/år i vestlige land $(1,2)$. Ca. $4 \%$ av alle epilepsipasienter har en tilgrunnliggende hjernesvulst (3). Aldersjustert insidens for ondartede primære hjernesvulster hos voksne er nå ca. 7/100 000/år i Norge (4). Den største gruppen av intrakraniale svulster, gliomene, deles i fire WHO-grupper basert på histologiske kjennetegn. Svulster av WHO-grad I og II omtales ofte som lavgradige gliomer. Grad I-svulstene (f.eks. gangliogliomer) er oftest kurable og residiverer svært sjelden. De skiller seg således vesentlig fra grad II-svulstene (f.eks. oligodendrogliomer), som residiverer innen 8-10 år hos de fleste pasientene. Svulstene av WHO-grad III (anaplastisk astrocytomer) og grad IV (glioblastomer) kalles høygradige gliomer og har et infiltrativt og aggressivt vekstmønster.

I denne artikkelen diskuterer vi epileptogenese, forekomst og behandling av epileptiske anfall hos pasienter med gliom. Epileptiske anfall forekommer også ved hjernemetastaser og ved godartede svulster som meningeomer, men bakgrunnen for anfall ved disse svulstene er mindre kartlagt enn ved gliomer (5). Overveiningene omkring bivirkningsprofil og interaksjonsproblematikk er imidlertid aktuelle også for pasienter med andre typer hjernesvulster og epilepsi.

\section{Klinisk presentasjon}

Forekomsten av epileptiske anfall er nært knyttet til histologisk diagnose (tab 1). Lavgradige svulster med langsom vekst er mest epileptogene (5-10). Fordi høygradig gliom er hyppigst, men epileptiske anfall er sjeldnere i denne gruppen, ligger prevalensen av epileptiske anfall for den samlede gliomgruppen på 30-60\% $(7,8) .85 \%$ av pasientene med gliom og epilepsi får sitt første anfall tidlig i forløpet, oftest som debutsymptom, mens $15 \%$ utvikler anfall senere $\mathrm{i}$ sykdomsforløpet (7).

Epileptiske anfall ved gliom har en fokal start med symptomer relatert til svulstlokalisasjon, men rask sekundær generalisering er vanlig, særlig på debuttidspunktet. Anfallet kan derfor feiltolkes som primært generalisert. Etter oppstart av svulstbehandling og antiepileptisk behandling er det vanligst med fokale anfall uten generalisering (7).

\section{Hovedbudskap}

- Epileptiske anfall er et hyppig symptom hos pasienter med gliom

- Hjernesvulst må alltid utelukkes hos voksne pasienter med nydiagnostisert epilepsi

- Antiepileptika uten enzyminduserende virkning bør foretrekkes

- Muligheten for interaksjoner mellom antiepileptika og annen medikasjon må alltid vurderes

- Antiepileptika kan påvirke våkenhet, stemningsleie og kognisjon og behandlingen må ta hensyn til dette 
Ved lavgradig gliom er epilepsi ofte eneste symptom, mens pasienter med høygradig gliom som regel har fokale nevrologiske utfall eller kognitive symptomer i tillegg.

Anfallshyppighet og alvorlighetsgrad varierer. Noen pasienter med hjernesvulst har kun ett eller noen få anfall i løpet av sykdomsforløpet, mens andre har epileptiske anfall flere ganger daglig. Særlig pasientene med høygradige svulster kan erfaringsmessig ha langvarige postiktale faser etter generaliserte anfall. Status epilepticus er relativt sjelden hos pasienter med hjernesvulst og opptrer oftest ved diagnosetidspunkt eller ved residiv (11). Økende anfallshyppighet, endret anfallskarakter eller sen anfallsdebut kan skyldes sykdomsprogresjon, og bildediagnostikk bør da gjøres (7).

\section{Mekanismer for utvikling av epilepsi ved hjernesvulst}

Epileptogenesen ved hjernesvulst er sannsynligvis multifaktoriell. Svulstens lokalisasjon og histologi er sentrale faktorer (12). Både selve svulsten og det omkringliggende vevet (peritumoral sone) kan gi opphav til epileptiske anfall, og molekylærbiologiske egenskaper ved tumor og mikromiljøet rundt den er derfor også av stor betydning (13).

\section{Lokalisasjon}

Kortikal affeksjon er nødvendig for at epileptiske anfall skal oppstå, og svulstene som gir epilepsi ligger nesten alltid supratentorialt. Cortex kan involveres direkte ved infiltrativ svulstvekst eller indirekte ved intrakranial trykkstigning.

Svulster i frontallappene gir oftere epileptiske anfall enn ved andre lokalisasjoner, mens temporal lokalisasjon er assosiert med behandlingsresistent epilepsi (14). Lavgradige gliomer oppstår oftere i epileptogene deler av hjernen, spesielt insula og supplementærmotorisk cortex (15).

\section{Histologi}

Epileptiske anfall er vanligst ved langsomtvoksende hjernesvulster (tab 1). 90-100\% av pasientene med gliom grad I har epileptiske anfall, men disse pasientene har oftest normal livslengde, noe som både gir flere år med mulige anfall og økt sannsynlighet for å utvikle epileptogene områder i eller rundt svulsten. $70-80 \%$ av pasienter med gliom grad II har epilepsi $(5,6,8,10)$. Mutasjoner i genene i lavgradige gliomer kan tenkes å være av felles betydning for svulstvekst og utvikling av epilepsi $(16,17)$. Pasienter med høygradig gliom har kort forventet levetid og dermed mindre tid til å utvikle epileptogene forandringer i synapser og reseptorer $(5,13)$. Her kan ødem, nekrose og økt intrakranialt trykk føre til anatomiske endringer i cortex og utløse epileptiske anfall. Likevel er forekomsten av epileptiske anfall lavere ved høygradige svulster. Det er derfor sannsynlig at også andre faktorer spiller inn, for eksempel kan økende dedifferensiering i en

Tabell 1 Forekomst av epilepsi i forskjellige undergrupper av gliomer. Variasjonene i prosentandeler skyldes antakelig dels forskjeller i inklusjonskriterier og dels forskjeller i oppfølgingslengde. I alle studiene rapporteres likevel en høyere forekomst av epileptiske anfall hos pasienter med lavgradige svulster (grad I-II) enn ved høygradige (grad III-IV)

\begin{tabular}{|lcccc} 
Studie & $\begin{array}{c}\text { Gliom } \\
\text { grad I (\%) }\end{array}$ & $\begin{array}{c}\text { Gliom } \\
\text { grad II (\%) }\end{array}$ & $\begin{array}{c}\text { Gliom } \\
\text { grad III (\%) }\end{array}$ & $\begin{array}{c}\text { Gliom } \\
\text { grad IV (\%) }\end{array}$ \\
\hline Lote et al (6) & - & 85 & 69 & 49 \\
\hline Hildebrand et al (7) & - & 46 & 30 & 15 \\
\hline Liigant et al (8) & - & 42 & 43 & 26 \\
\hline Chang et al (9) & - & 81 & - & - \\
\hline Zentner et al (10) & $92 \% 1$ & - & - & - \\
\hline 'Kun gangliogliomer var inkludert & & & & \\
\hline
\end{tabular}

høymalign svulst tenkes å gi tap av epileptogene egenskaper $(5,13,14)$.

\section{Molekylærbiologiske forhold}

Mange primære hjernesvulster uttrykker høye nivåer av proteiner som kan redusere medikamenttransport inn i cellene (multimedikamentresistensproteiner) og dermed redusere effekten av både kjemoterapeutika og antiepileptika, men det er omstridt om dette er av klinisk relevans $(5,18)$. Nedsatt reseptorsensitivitet, aktivering av glutamatreseptorer og tap av inhibitoriske synapser i svulstceller kan også være av betydning for utvikling av epileptiske anfall $(13,14)$. Ny forskning gir holdepunkt for at epileptiske anfall ved gliom medieres via glutamat som frigjøres fra tumorcellene via transportsystemer som kan være unike for denne typen epilepsi (19).

\section{Peritumoralt miljø}

Primære hjernesvulster påvirker det omkringliggende hjernevevet på mange og potensielt epileptogene måter. Laktat- og glutamatkonsentrasjonen i den peritumorale sonen er oftest høyere enn normalt og miljøet er lett acidotisk. Det gjør at membranpotensialet i nevronene endres og eksitabiliteten øker (14). Oppregulering av eksitatoriske NMDAreseptorer og endring av aktivitet $i$ inhibitoriske GABA-reseptorer er påvist i svulstvev $(14,20,21)$. Spesielt ved lavgradige svulster kan den peritumorale sonen være like sentral som svulstcellene i epileptogenesen (14).

\section{Utredning}

Alle voksne pasienter med nyoppstått epilepsi bør utredes med magnettomografisk undersøkelse (MR) av hjernen med T1- og T2-vektede serier og med og uten kontrast. Særlig ved lavgradige svulster kan epileptiske anfall opptre lenge før andre symptomer, og av og til også før sikre radiologiske forandringer kan påvises (22). Det er derfor viktig å følge opp voksne pasienter med epilepsi av ukjent årsak, spesielt ved fokal anfallsstart eller fokal patologi ved elektroencefalografi (EEG). Ved usikre radiologiske funn, gjentatte anfall eller fokal EEG-patologi bør MR gjentas $(4,8)$. Risikoen for å få påvist hjernesvulst er bety- delig økt i flere år etter et førstegangs epileptisk anfall hos en voksen (22). EEG bør gjøres av alle pasienter. I noen tilfeller kan EEGvideometri være nødvendig.

\section{Antiepileptisk behandling}

Behandling med antiepileptika bør startes hos alle pasienter med hjernesvulst som har hatt et epileptisk anfall. Lokalisasjonsrelatert symptomatisk epilepsi er generelt vanskeligere å behandle enn generalisert epilepsi $(5$, $21,23)$. Opptil $60 \%$ av pasientene har fortsatt anfall etter oppstart av det første medikamentet, og kombinasjonsbehandling med flere antiepileptika kan være nødvendig $(5,7)$.

Profylaktisk bruk av antiepileptika frarådes generelt hos pasienter som aldri har hatt anfall $(5,24)$, også i den peri- og postoperative fasen $(5,24)$. Ved symptomer som gir mistanke om epileptiske anfall hos en pasient med gliom bør det være lav terskel for EEG og vurdering hos nevrolog.

Medikamentvalg ved epilepsi hos pasienter med gliom må gjøres ut fra forventet effekt, interaksjons- og bivirkningsprofil. En del eldre antiepileptika metaboliseres via leverens cytokrom P-450-enzymsystem og kan virke inhiberende eller induserende på dette systemet $(5,21)$ (tab 2). Enzyminduserende antiepileptiske medikamenter som karbamazepin og okskarbazepin velges fortsatt ofte til gliompasienter $(7,21,25)$, men midler uten enzympåvirkning, derav mange nyere antiepileptika, brukes i økende grad (tab 2). Generelt har valproat, okskarbazepin, levetiracetam, lakosamid, topiramat, zonisamid og pregabalin vist god anfallsforebyggende effekt. 50-88\% har oppnådd anfallsfrihet (26-32), og levetiracetam og gabapentin har også god effekt som tilleggsbehandling til andre antiepileptika (26, 33). Studiene er imidlertid ofte små, og i en Cochrane-oversikt konkluderes det med at det bør gjøres større randomiserte studier for å sammenlikne de ulike medikamentenes effekt (34). Det er imidlertid internasjonal enighet om at hos gliompasienter har de nyere medikamentene uten enzympåvirkning sannsynligvis minst like god og kanskje bedre antiepileptisk effekt enn de enzyminduserende midlene (35) (tab 2). Levetiracetam foretrekkes nå av mange som førstehåndspreparat $(5,35)$, og 
Tabell 2 Oversikt over antiepileptika som er i vanlig bruk ved gliom og deres fordeler og ulemper for denne pasientgruppen. Noen nyere antiepileptika er ikke tatt med, da de foreløpig er i liten bruk til gliompasienter og det ikke foreligger studier av bruk i denne pasientgruppen. Fenytoin og fenobarbital er nå relativt lite brukt. Ytterligere informasjon finnes i Felleskatalogen

\begin{tabular}{|c|c|c|}
\hline Medikament & Bivirkninger og ulemper & Fordeler \\
\hline Karbamazepin & $\begin{array}{l}\text { Sedasjon } \\
\text { Endret kognisjon } \\
\text { Hematologisk påvirkning } \\
\text { Enzyminduserende egenskaper }\end{array}$ & $\begin{array}{l}\text { Raskt innsettende effekt } \\
\text { Tilgjengelig som mikstur/supp }\end{array}$ \\
\hline Fenytoin & $\begin{array}{l}\text { Sedasjon } \\
\text { Endret kognisjon } \\
\text { Hematologisk påvirkning } \\
\text { Enzyminduserende egenskaper }\end{array}$ & $\begin{array}{l}\text { Raskt innsettende effekt } \\
\text { Fosfenytoin er tilgjengelig som } \\
\text { intravenøst }\end{array}$ \\
\hline Fenobarbital & $\begin{array}{l}\text { Sedasjon } \\
\text { Endret kognisjon } \\
\text { Hematologisk påvirkning } \\
\text { Enzyminduserende egenskaper }\end{array}$ & Raskt innsettende effekt \\
\hline Okskarbamazepin & $\begin{array}{l}\text { Sedasjon } \\
\text { Endret kognisjon } \\
\text { Hematologisk påvirkning } \\
\text { Enzyminduserende egenskaper }\end{array}$ & $\begin{array}{l}\text { Raskt innsettende effekt } \\
\text { Tilgjengelig som mikstur/supp }\end{array}$ \\
\hline Valproat & $\begin{array}{l}\text { Hematologisk påvirkning } \\
\text { Enzyminhiberende egenskaper }\end{array}$ & $\begin{array}{l}\text { Stemningsstabiliserende } \\
\text { Tilgjengelig som intravenøst/mikstur }\end{array}$ \\
\hline Levetirazetam & $\begin{array}{l}\emptyset \text { ket irritabilitet } \\
\text { Depresjon }\end{array}$ & $\begin{array}{l}\text { Rask titrering, intravenøst/mikstur } \\
\text { Sjelden hematologisk påvirkning }\end{array}$ \\
\hline Lamotrigin & Langvarig titrering & Stemningsstabiliserende \\
\hline Topiramat & $\begin{array}{l}\text { Hematologisk påvirkning } \\
\text { Psykiske/kognitive bivirkninger } \\
\text { Sedasjon }\end{array}$ & \\
\hline Pregabalin & $\begin{array}{l}\text { Sedasjon } \\
\text { Kognitiv påvirkning } \\
\text { Svimmelhet } \\
\text { Langvarig titrering }\end{array}$ & $\begin{array}{l}\text { Anxiolytisk } \\
\text { Smertestillende effekt }\end{array}$ \\
\hline Gabapentin & Langvarig titrering & $\begin{array}{l}\text { Anxiolytisk } \\
\text { Smertestillende effekt }\end{array}$ \\
\hline Lakosamid & $\begin{array}{l}\text { Hodepine } \\
\text { Svimmelhet }\end{array}$ & $\begin{array}{l}\text { Sjelden hematologisk påvirkning } \\
\text { Tilgjengelig som intravenøst/mikstur }\end{array}$ \\
\hline Zonisamid & $\begin{array}{l}\text { Hepatisk metabolisme } \\
\text { Psykiske og kognitive bivirkninger }\end{array}$ & \\
\hline Diazepam & $\begin{array}{l}\text { Sedasjon } \\
\text { Kognitive bivirkninger } \\
\text { Avhengighet } \\
\text { Kortvarig effekt }\end{array}$ & $\begin{array}{l}\text { Rask effekt } \\
\text { Tilgjengelig som intravenøst/supp }\end{array}$ \\
\hline Klonazepam & $\begin{array}{l}\text { Sedasjon } \\
\text { Kognitive bivirkninger } \\
\text { Takyfylaksi med behov for økt dose }\end{array}$ & Anxiolytisk effekt \\
\hline
\end{tabular}

kan kombineres med de fleste andre antiepileptiske midler.

Fastende medikamentspeil i serum bør tas iallfall 1-2 ganger i året og ved manglende anfallskontroll, interaksjonsmistanke eller etterlevelsesproblemer. EEG bør tas ved diagnostisk usikkerhet eller ved mistanke om status epilepticus.

Seponering av antiepileptika kan vurderes hos anfallsfrie pasienter der svulsten er vellykket behandlet, for eksempel etter 3-5 års anfallsfrihet. Dette er mest aktuelt hos pasienter med lavgradig gliom. Anfallsrisiko og sosiale konsekvenser av nye anfall må diskuteres med pasienten. Ved høygradig gliom er det så høy risiko for svulstresidiv at seponering oftest ikke er tilrådelig (21).

I livets sluttfase gjøres ofte nedtrapping av ødembehandling (deksametason), og dette mid (38). Imidlertid medførte valproatbruk mer uttalt hematologisk toksisitet. Studien er derfor ikke entydig positiv for valproat og må tolkes med forsiktighet (39). Det er også data som tyder på at levetiracetam kan hemme gliomcellevekst (40).

Det er rapportert at bruk av enzyminduserende antiepileptika var assosiert med signifikant dårligere overlevelse enn ikkeenzyminduserende midler hos glioblastompasienter under behandling med lomustin (41), og dette ble tilskrevet interaksjoner med kjemoterapien, men andre har ikke funnet en slik effekt (42).

\section{Bivirkninger og interaksjoner}

Pasienter med hjernesvulst har oftere bivirkninger av antiepileptisk behandling enn andre epilepsipasienter (21). Bivirkninger kan være vanskelig å skille fra svulstsymptomer og behandlingssekveler. Pasientene er særlig utsatt for sedasjon og kognitive bivirkninger, særlig ved kombinasjonsbehandling med flere antiepileptika (43). Nyere antiepileptika gir mindre sedasjon enn de eldre midlene, men kan ha psykiske effekter som depresjon og irritabilitet. Dette bør man være spesielt oppmerksom på i denne pasientgruppen.

Ved oppstart av epilepsibehandling til en pasient som skal gjennomgå kjemoterapi eller bruker deksametason må interaksjonsfaren alltid vurderes $(44,45)$. Mange kjemoterapeutiske midler har også hepatisk metabolisme. Interaksjoner mellom kjemoterapeutika og antiepileptika kan derfor potensielt påvirke effekten av en eller begge typer medikamenter. Nyere antiepileptika har liten eller ingen hepatisk metabolisme og ofte lav eller ingen proteinbinding ( $\operatorname{tab} 2$ ). Dette reduserer faren for interaksjoner betydelig.

I Norge brukes temozolomid rutinemessig ved behandling av høygradige gliomer. Kombinasjonsbehandling med prokarbazin, lomustin og vinkristin (PCV-regimet) kan være aktuelt ved noen gliomtyper. Temozolomid gir hyppig beinmargstoksisitet (46). Eldre antiepileptika kan gi leukopeni, trombocytopeni og andre hematologiske bivirkninger, og kombinasjonen med temozolomid kan potensielt ha en additiv effekt på beinmargen (34). Vår erfaring er at hematologiske bivirkninger er et mindre problem ved bruk av nyere antiepileptika, men litteraturen er svært sparsom. Temozolomid påvirker ikke plasmanivåene av okskarbazepin eller topiramat (47). Valproat reduserer clearance av temozolomid med ca. $5 \%$. Den kliniske betydningen av dette er ukjent (38). Utover dette vet man lite om potensielle interaksjoner mellom temozolomid og antiepileptika.

Vinkristin er en enzyminhibitor som interagerer med enkelte antiepileptika (e-tab 3) $(35,36)$. Bevacizumab brukes til enkelte gliompasienter med residiv. Verken bevacizumab eller temozolomid metaboliseres via leveren $(5,46)$.

Interaksjoner mellom deksametason og 
enzyminduserende antiepileptika er vanlig (e-tab 3) $(5,48)$. Ved svingende serumspeil eller dårlig effekt av antiepileptiske medikamenter i kombinasjon med deksametason bør det derfor overveies om medikamentinteraksjon kan være årsaken.

\section{Medikamentutløste anfall}

Antipsykotika og eldre antidepressiver kan potensielt senke anfallsterskelen. Adekvat behandling med nyere antidepressiver medfører sannsynligvis liten risiko for økt anfallsaktivitet. Adekvat behandling av depresjon kan også virke gunstig på epilepsien (49). Skifte av antiepileptika kan generelt forverre anfallssituasjonen hos noen pasienter.

\section{Antiepileptisk effekt av kirurgisk og onkologisk behandling}

Hvis mulig vil kirurgisk reseksjon av svulsten alltid være førstevalg i behandlingen av gliom. Særlig ved lavgradig gliom kan radikal reseksjon ofte redusere postoperativ anfallsfrekvens betydelig, og ved reseksjon av hele den epileptogene sonen kan mange bli anfallsfrie $(5,9)$. Peroperativ kortikografi med kartlegging av epileptogen sone kan tenkes å gi en ytterligere gevinst hos noen pasienter med lavgradig gliom, men gjøres relativt sjelden.

Strålebehandling gis ved høygradig gliom og ved residiv av lavgradig gliom. Stråleindusert ødem i tumorområdet kan gi økt anfallstendens, men i praksis reduserer strålebehandling og kjemoterapi anfallsfrekvensen hos de fleste pasientene $(5,50,51)$. Opptrapping av deksametason etter behov kan forebygge anfall under strålebehandlingen.

\section{Bilkjøring ved gliom og epilepsi}

Førerkortforskriftenes helsekrav for anfallsfrihet er i utgangspunktet som ved andre typer epilepsi. De generelle helsekravene for førlighet, synsfelt og kognitiv funksjon er spesielt aktuelle, og kognitive utfall blir sannsynligvis underdiagnostisert i denne pasientgruppen. Et tilleggsproblem er at sykdomsprogresjon kan medføre nye symptomer eller forverret anfallssituasjon i løpet av kort tid. Egnethet for bilkjøring må derfor vurderes fortløpende, særlig ved høygradig gliom, og vurderingen bør journalføres. Manglende egnethet for bilkjøring skal meldes til fylkeslege.

\section{Livskvalitet og \\ nevropsykologiske aspekter}

Både epileptiske anfall og antiepileptisk behandling kan påvirke kognitiv funksjon og livskvalitet (43). Pasienter med gliom som bruker antiepileptika har dårligere kognitiv funksjon enn pasienter uten epilepsi, uavhengig av svulstens beliggenhet og gjennomgått behandling (52). Samtidig er økende anfallsaktivitet også assosiert med kognitive problemer. Det er usikkert om dette skyldes gliomenes infiltrerende karakter, anfallsaktivitet, behandling eller bivirk- ninger av behandlingen, men man må anta at årsakene er sammensatte og med store individuelle variasjoner. Samlet sett anbefales det at epilepsi hos pasienter med hjernesvulst alltid bør behandles. Ikke-medikamentell behandling, som et tverrfaglig tilbud hvor de ulike profesjonene har erfaring med epilepsi og livstilpassing, kan ha stor tilleggsverdi.

\section{Konklusjon}

Epilepsi ved gliom er vanlig og kan være behandlingsmessig vanskelig. Anfallsreduksjon eller anfallsfrihet må likevel være målet, og den antiepileptiske behandlingen bør derfor være offensiv. Behandlingen bør monitoreres slik at påvirkning av våkenhet, stemningsleie og kognisjon unngås i størst mulig grad. Ved samtidig bruk av kjemoterapi og antiepileptika med potensiell hematologisk påvirkning bør blodbildet overvåkes spesielt nøye. Til det foreligger større studier der man sammenlikner effekt og bivirkninger av de ulike medikamentene anbefaler vi at antiepileptika uten enzyminduserende effekter er førstevalg til disse pasientene.

\section{e-tab 3 finnes kun i Tidsskriftets nettutgave.}

\section{Kathrine Lian (f. 1980)}

er lege i spesialisering ved Nevrologisk avdeling. Forfatter har fylt ut ICMJE-skjemaet og oppgir følgende interessekonflikter: Hun har mottatt reisestøtte fra Schering-Plough, som markedsfører temozolomid.

\section{Anette Storstein (f. 1966)}

er dr.med., spesialist i nevrologi og overlege. Forfatter har fylt ut ICMJE-skjemaet og oppgir følgende interessekonflikter: Hun har mottatt foredragshonorar og reisest $\varnothing$ tte fra UCB Pharma og Schering-Plough.

\section{Bernt Engelsen (f. 1951)}

er dr.med., spesialist i nevrologi, overlege og professor.

Forfatter har fylt ut ICMJE-skjemaet og oppgir følgende interessekonflikter: Han har mottatt reisestøtte fra UCB Pharma, Eisai og GSK samt foredragshonorar fra UCB Pharma, GSK og Novartis.

\section{Litteratur}

Sander JW. The epidemiology of epilepsy revisited. Curr Opin Neurol 2003; 16: 165-70.

2. MacDonald BK, Cockerell OC, Sander JW et al. The incidence and lifetime prevalence of neurological disorders in a prospective community-based study in the UK. Brain 2000; 123: 665-76.

3. Herman ST. Epilepsy after brain insult: targeting epileptogenesis. Neurology 2002; 59 (suppl 5): S21-6.

4. Cancer Registry of Norway. Cancer in Norway 2009 - Cancer incidence, mortality, survival and prevalence in Norway. Oslo: Cancer Registry of Norway, 2011

5. Rudà R, Trevisan E, Soffietti R. Epilepsy and brain tumors. Curr Opin Oncol 2010; 22: 611-20.

6. Lote K, Stenwig AE, Skullerud K et al. Prevalence and prognostic significance of epilepsy in patients with gliomas. Eur J Cancer 1998; 34: 98-102.

7. Hildebrand J, Lecaille C, Perennes J et al. Epileptic seizures during follow-up of patients treated fo primary brain tumors. Neurology 2005; 65: 212-5.

8. Liigant A, Haldre S, ? un A et al. Seizure disorders in patients with brain tumors. Eur Neurol 2001; 45: $46-51$.

9. Chang EF, Potts MB, Keles GE et al. Seizure char acteristics and control following resection in 332 patients with low-grade gliomas. J Neurosurg 2008; 108: 227-35.

10. Zentner J, Wolf HK, Ostertun B et al. Gangliogliomas: clinical, radiological, and histopathological findings in 51 patients. J Neurol Neurosurg Psychiatry 1994; 57: 1497-502.

11. Cavaliere R, Farace E, Schiff D. Clinical implications of status epilepticus in patients with neoplasms. Arch Neurol 2006; 63: 1746-9.

12. Rosati A, Tomassini A, Pollo B et al. Epilepsy in cerebral glioma: timing of appearance and histological correlations. J Neurooncol 2009; 93 395-400.

13. Smits A, Storstein A. Tumor-associated epilepsy in patients with glioma. I: Tumors of the Central Nervous System. Kapittel 39. Heidelberg: Springer Science+Business Media, 2011

14. Shamji MF, Fric-Shamji EC, Benoit BG. Brain tumors and epilepsy: pathophysiology of peritumoral changes. Neurosurg Rev 2009; 32: 275-84, discussion 284-6.

15. Duffau H, Capelle L. Preferential brain locations of low-grade gliomas. Cancer 2004: 100: 2622-6.

16. Berntsson SG, Malmer B, Bondy ML et al. Tumor associated epilepsy and glioma: are there common genetic pathways? Acta Oncol 2009; 48: 955-63.

17. Huang $L$, You G, Jiang $T$ et al. Correlation between tumor-related seizures and molecular genetic profile in 103 Chinese patients with low-grade gliomas: a preliminary study. J Neurol Sci 2011 302: 63-7.

18. Aronica E, Gorter JA, Redeker S et al. Localization of breast cancer resistance protein (BCRP) in microvessel endothelium of human control and epileptic brain. Epilepsia 2005; 46: 849-57.

19. Buckingham SC, Campbell SL, Haas BR et al. Glutamate release by primary brain tumors induces epileptic activity. Nat Med 2011; 17: 1269-74.

20. Tang CM, Dichter M, Morad M. Modulation of the $\mathrm{N}$-methyl-D-aspartate channel by extracellular H+. Proc Natl Acad Sci U S A 1990; 87: 6445-9.

21. van Breemen MS, Wilms EB, Vecht CJ. Epilepsy in patients with brain tumours: epidemiology, mechanisms, and management. Lancet Neurol 2007: 6: $421-30$.

22. Khan T, Akhtar W, Wotton CJ et al. Epilepsy and the subsequent risk of cerebral tumour: record linkage retrospective cohort study. J Neurol Neurosurg Psychiatry 2011; 82: 1041-5.

23. Kwan P. Brodie MJ. Early identification of refractory epilepsy. N Engl J Med 2000; 342: 314-9.

24. Glantz MJ, Cole BF, Forsyth PA et al. Practice parameter: anticonvulsant prophylaxis in patients with newly diagnosed brain tumors. Neurology 2000: 54: 1886-93

25. Vecht CJ, van Breemen M. Optimizing therapy of seizures in patients with brain tumors. Neurology 2006; 67 (suppl 4): S10-3

26. van Breemen MS, Rijsman RM, Taphoorn MJ et at. Efficacy of anti-epileptic drugs in patients with gliomas and seizures. J Neurol 2009; 256: 1519-26

27. Maschio M. Dinapoli L, Sperati F et al. Oxcarbazepine monotherapy in patients with brain tumorrelated epilepsy: open-label pilot study for assessing the efficacy, tolerability and impact on quality of life. J Neurooncol 2012; 106: 651-6.

28. Newton HB, Goldlust SA, Pearl D. Retrospective analysis of the efficacy and tolerability of levetiracetam in brain tumor patients. J Neurooncol 2006 78: $99-102$

29. Maschio M Dinapoli L, Mingoia M et al. Lacosamide as add-on in brain tumor-related epilepsy: preliminary report on efficacy and tolerability. J Neurol 2011; 258: 2100-4

30. Maschio M, Dinapoli L, Zarabla A et al. Outcome and tolerability of topiramate in brain tumor associated epilepsy. J Neurooncol 2008; 86: 61-70. 
31. Maschio M, Dinapoli L, Saveriano F et al. Efficacy and tolerability of zonisamide as add-on in brain tumor-related epilepsy: preliminary report. Acta Neurol Scand 2009; 120: 210-2.

32. Novy J, Stupp R, Rossetti AO. Pregabalin in patients with primary brain tumors and seizures: a preliminary observation. Clin Neurol Neurosurg 2009; 111: 171-3.

33. Perry JR, Sawka C. Add-on gabapentin for refractory seizures in patients with brain tumours. Can J Neurol Sci 1996; 23: 128-31.

34. Kerrigan S, Grant R. Antiepileptic drugs for treating seizures in adults with brain tumours (Review). Cochrane Database Syst Rev 2011; nr. 8: CD008586.

35. Rossetti AO, Stupp R. Epilepsy in brain tumor patients. Curr Opin Neurol 2010; 23: 603-9.

36. Eyal S, Yagen B, Sobol E et al. The activity of antiepileptic drugs as histone deacetylase inhibitors. Epilepsia 2004; 45: 737-44.

37. Chen CH, Chang YJ, Ku MSB et al. Enhancement of temozolomide-induced apoptosis by valproic acid in human glioma cell lines through redox regulation. J Mol Med (Berl) 2011; 89: 303-15.

38. Weller M, Gorlia T, Cairncross JG et al. Prolonged survival with valproic acid use in the EORTC/NCIC temozolomide trial for glioblastoma. Neurology 2011: 77: 1156-64

39. Wen PY, Schiff D. Valproic acid as the AED of choice for patients with glioblastoma? The jury is out. Neurology 2011; 77: 1114-5.

40. Bobustuc GC, Baker CH, Limaye A et al. Levetiracetam enhances p53-mediated MGMT inhibition and sensitizes glioblastoma cells to temozolomide. Neuro Oncol 2010; 12: 917-27.

41. Oberndorfer S, Piribauer M, Marosi C et al. P450 enzyme inducing and non-enzyme inducing antiepileptics in glioblastoma patients treated with standard chemotherapy. J Neurooncol 2005; 72 255-60.

42. Jaeckle KA, Ballman K, Furth A et al. Correlation of enzyme-inducing anticonvulsant use with outcome of patients with glioblastoma. Neurology 2009; 73: 1207-13.

43. Klein M, Engelberts NH, van der Ploeg HM et al. Epilepsy in low-grade gliomas: the impact on cognitive function and quality of life. Ann Neurol 2003; 54: 514-20.

44. Vecht CJ, Wagner GL, Wilms EB. Interactions between antiepileptic and chemotherapeutic drugs. Lancet Neurol 2003; 2: 404-9.

45. Interaksjonsdatabase for norske klinikere. www.interaksjoner.no (25.6.2012).

46. Hart MG, Grant R, Garside R et al. Temozolomide for high grade glioma. Cochrane Database Syst Rev 2008; nr. 4: CD007415.

47. Maschio M, Albani F, Jandolo B et al. Temozolomide treatment does not affect topiramate and oxcarbazepine plasma concentrations in chronically treated patients with brain tumor-related epilepsy. J Neurooncol 2008; 90: 217-21.

48. Roth P, Wick W, Weller M. Steroids in neurooncology: actions, indications, side-effects. Curr Opin Neurol 2010; 23: 597-602.

49. Noe KH, Locke DEC, Sirven JI. Treatment of depression in patients with epilepsy. Curr Treat Options Neurol 2011; 13: 371-9

50. Chalifoux R, Elisevich K. Effect of ionizing radiation on partial seizures attributable to malignant cerebral tumors. Stereotact Funct Neurosurg 1996-1997-1997; 67: 169-82.

51. Rogers LR, Morris HH, Lupica K. Effect of cranial irradiation on seizure frequency in adults with low-grade astrocytoma and medically intractable epilepsy. Neurology 1993; 43: 1599-601.

52. Klein M, Heimans JJ, Aaronson NK et al. Effect of radiotherapy and other treatment-related factors on mid-term to long-term cognitive sequelae in low-grade gliomas: a comparative study. Lancet 2002; 360: 1361-8.

Mottatt 17.11. 2011, første revisjon innsendt 23.12. 2011, godkjent 26.4. 2012. Medisinsk redaktør Jon Amund Kyte. 